\title{
Short communication: Effect of stocking rate on the economics of pasture-based dairy farms
}

\author{
K. A. Macdonald, ${ }^{\star}$ D. Beca, $†$ J. W. Penno, ${ }^{\star 1}$ J. A. S. Lancaster, ${ }^{\star}$ and J. R. Roche ${ }^{\star 2}$ \\ *DairyNZ, Private Bag 3221, Hamilton 3240, New Zealand \\ †Red Sky Agricultural Pty. Ltd., 187 Main St, Bacchus Marsh, VIC 3340, Australia
}

\begin{abstract}
Data from a multiyear farm systems study evaluating the effect of stocking rate (SR) on pasture production and utilization, milk production per cow and per hectare, reproduction, and cow health were used to determine the economic implications of altering SR. The effect of SR was also evaluated relative to cow size and total feed available (comparative stocking rate; CSR), to account for differences in cow size and feed supplement availability. Milk production, gross revenue, operating expenses, and operating profit per cow all declined with increasing SR and CSR. In comparison, milk production, gross revenue, and operating expenses per hectare increased with increasing SR and CSR. These effects were irrespective of milk price. The effect of SR on operating profit and return on assets, however, was dependent on milk payment system. When payment was based on the economic value of milk fat and protein, operating profit and return on assets were quadratically associated with both SR and CSR, declining at an SR greater or less than 3.3 cows/ha and a CSR greater or less than $77 \mathrm{~kg}$ of body weight/t of feed dry matter available. In comparison, when milk payment was based on a fluid milk pricing system, profit per hectare increased linearly with increasing SR and CSR, but return on assets was not affected by SR or CSR.

Key words: comparative stocking rate, operating profit, operating expense, return on assets
\end{abstract}

\section{Short Communication}

There has been a rejuvenated interest in pasturebased dairy production systems internationally, primarily because of reductions in inflation-adjusted milk prices globally (Dillon et al., 2005). Pasture-based systems present an opportunity for lower operating expenses compared with TMR-based confinement op-

Received August 5, 2010.

Accepted December 13, 2010.

${ }^{1}$ Current address: Synlait Ltd., RD 13, Rakaia, New Zealand.

${ }^{2}$ Corresponding author: john.roche@dairynz.co.nz erations, but milk production per cow is less (White et al., 2002; Dillon et al., 2005). Hanson et al. (1998) and Kriegl (2001) acknowledged the potential profitability of grazing dairy systems in the United States when systems are managed appropriately. Appropriate management involves assigning the correct stocking rate (SR; Macdonald et al., 2008) to match the seasonal supply of pasture with the herd intake demand as closely as possible (Dillon et al., 1995). This facilitates very high utilization of feed grown.

Stocking rate is generally defined as the number of animals allocated to an area of land (i.e., cows/ha). However, Macdonald et al. (2008) identified limitations to using SR in comparisons across dairy businesses. Differences between farms in land class, soil fertility, climate, climate variability, and the availability and price of supplements influence the amount of feed available per hectare. Additionally, differences in cow breed and genetic merit alter cow requirements. Together, these variables make it difficult to extrapolate and compare results from different SR experiments. To overcome this, Macdonald et al. (2008) introduced the concept of comparative SR (CSR), which was defined as kilograms of cow BW (at a standard BCS) per tonne of feed DM available, using BW as a proxy for the cows' genetic merit for milk production, and making the assumption that most feeds offered to dairy cattle were similar in ME content (between 10.5 and $12 \mathrm{MJ}$ of $\mathrm{ME} / \mathrm{kg}$ of $\mathrm{DM}$ ).

Although SR has been evaluated many times over the last half century (McMeekan, 1956; Castle et al., 1972; Gordon, 1973; Baker and Leaver, 1986; Dillon et al., 1995; Fales et al., 1995; Kennedy et al., 2006), the foci were primarily on milk production changes from altering SR, with very few studies (Fales et al., 1995) providing economic analyses. In addition, apart from Macdonald et al. (2008), previous SR studies undertaken in temperate climatic zones investigated a maximum of $3 \mathrm{SR}$ treatments, making it impossible to define an optimum SR or CSR, even if economic analyses were undertaken. The profitability of pasture-based dairy systems depends on the efficiency of pasture use coupled with reasonable production per cow (Dillon et 
Table 1. Effect of stocking rate on pasture growth and utilization, silage consumed, the proportion of the farm mechanically cut to maintain pasture quality (topped), milk production, and lactation length (adapted from Macdonald et al., 2008)

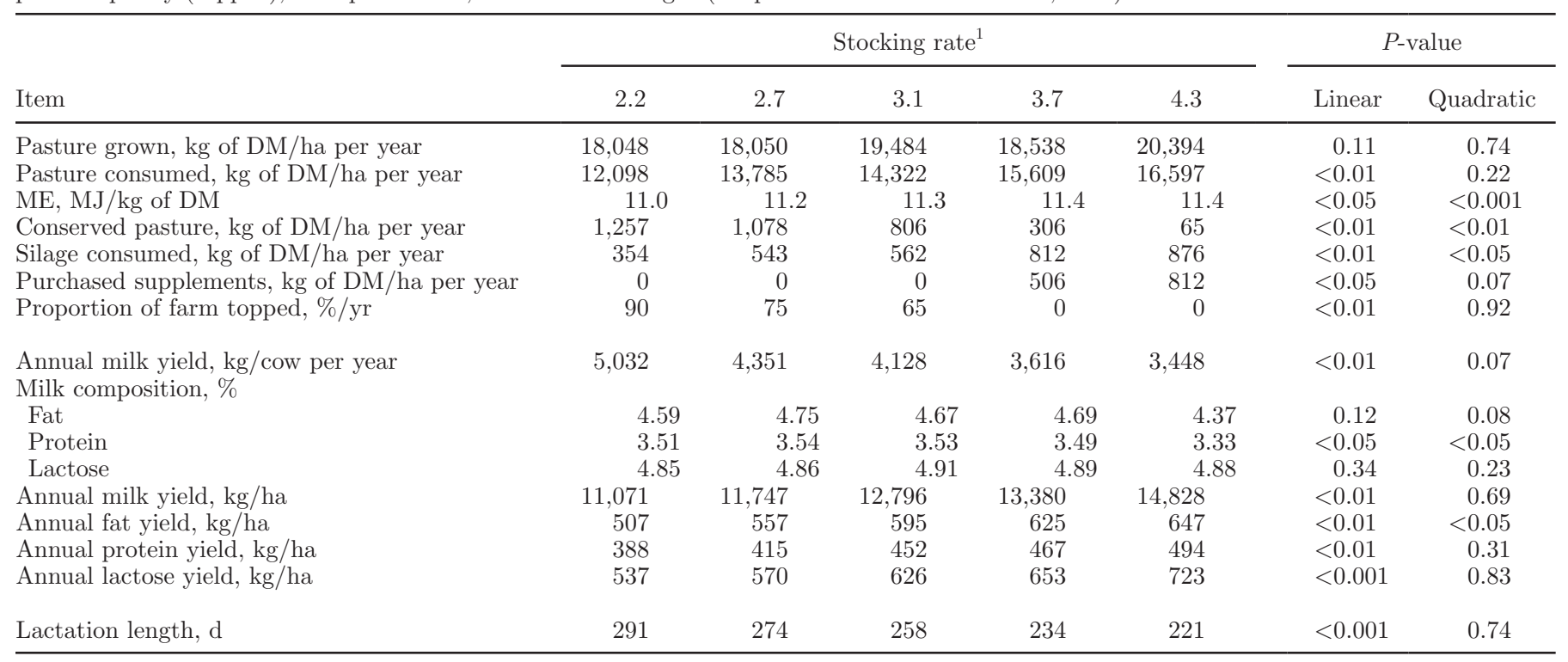

${ }^{1}$ These stocking rates are equivalent to comparative stocking rates ( $\mathrm{kg}$ of $\mathrm{BW} / \mathrm{t}$ of feed $\mathrm{DM}$ ) of $60,70,76,89$, and 91, respectively.

al., 2005). Macdonald et al. (2008) reported decreasing milk yield per cow but increasing milk production per hectare with increasing SR, implying that there is likely an SR and CSR that maximizes profitability. Production data from Macdonald et al. (2008) and associated operating expenses were used to evaluate the economic implications of altering SR and CSR.

The experiment was undertaken at No. 2 Dairy Farm, DairyNZ, Hamilton, New Zealand (latitude $37^{\circ} 47^{\prime}$ S, longitude $175^{\circ} 19^{\prime} \mathrm{E}, 40 \mathrm{~m}$ above sea level) over 3 years, and methods were reported in detail by Macdonald et al. (2008). Briefly, 94 Holstein-Friesian cows were randomly allocated to 1 of 5 SR farmlets $(2.2,2.7,3.1,3.7$, and 4.3 cows/ha) in a completely randomized design; the CSR equivalent to the SR imposed was expected to be $62,76,90,103$, and $120 \mathrm{~kg}$ of $\mathrm{BW} / \mathrm{t}$ of $\mathrm{DM}$ per year, respectively, assuming pasture production per hectare was the same on all treatments $(18.0 \mathrm{t}$ of DM pasture was grown/ha per year; McGrath et al., 1998), and no feeds were acquired externally to the grazing platform. This would have been equivalent to an annual feed allowance of $8.1,6.8,5.8,4.9$, and $4.2 \mathrm{t}$ of $\mathrm{DM} /$ cow per year for $2.2,2.7,3.1,3.7$, and 4.3 cows/ha SR treatments, respectively. As outlined by Macdonald et al. (2008), however, and presented in Table 1, pasture grown tended $(P=0.11)$ to increase, pasture consumed increased linearly $(P<0.01)$, and cow BW decreased with SR. As a result, actual CSR was $60,70,76,89$, and $91 \mathrm{~kg}$ of BW/t of DM for 2.2, 2.7, 3.1, 3.7, and 4.3 cows/ha, respectively, using the BW of the cows in mo 6. This is equivalent to an annual allowance of 8.2, 6.7, $6.3,5.1$, and $4.9 \mathrm{t}$ of $\mathrm{DM} /$ cow, respectively.
The farms were managed as seasonal calving systems, with cows calving over an 8-wk period in spring. Approximately $20 \%$ of cows from each farmlet were culled each lactation, on the basis of reproductive failure, health, age, and genetic merit, and were replaced with primiparous cows 1 mo before the planned start of calving. Age structure did not differ across treatments.

Grazing management decision rules were the same across treatments, with the exception of intergrazing interval (rotation length), which was managed to optimize each individual treatment (see Macdonald et al., 2008). Defined grazing areas (paddocks) were grazed in rotational order, with cows only returning to the same area when more than 2 leaves had appeared on more than $66 \%$ of perennial ryegrass tillers.

Individual cow milk yields were recorded weekly (Tru-Test milk meter system, Palmerston North, New Zealand). Milk fat, CP, and lactose concentrations were determined on composite afternoon and morning aliquots by Fossomatic FT120 (Foss Electric, Hillerød, Denmark). Body weight and BCS were determined every second week following the morning milking or at approximately $0900 \mathrm{~h}$ during the nonlactating period. Body condition score was assessed pre- and postcalving on a 10-point scale, where 1 is emaciated and 10 is obese (Roche et al., 2004). Mastitis and other health problems and reproductive data were recorded.

Annual milk yield and milk component yield were calculated for each treatment. Milk was valued in 2 ways to reflect a milk component market price, representative of the globally traded value of fat and protein products (hereafter, milksolids price) and a fluid mar- 
ket milk price (hereafter, milk price), where milk composition was not considered. The base milksolids price was NZ $\$ 4.30$ (US $\$ 3.25$ at US $\$ 0.75 / \mathrm{NZ} \$ 1$ ) and reflected a price of $\mathrm{NZ} \$ 3 / \mathrm{kg}$ of milk fat and $\mathrm{NZ} \$ 6 / \mathrm{kg}$ of milk protein. The sensitivity of operating profit to milksolids price was evaluated at $\mathrm{NZ} \$ 5.30$ and $\mathrm{NZ} \$ 6.30$ (US\$4.00 and US $\$ 4.75 / \mathrm{kg}$, respectively). Milk price used was $\mathrm{NZ} \$ 0.32 / \mathrm{kg}$ of milk; this is equivalent to US\$10.90/ cwt of fluid milk at US $\$ 0.75 / \mathrm{NZ} \$$. The sensitivity of operating profit to milk price was evaluated at NZ $\$ 0.42$ and NZ $\$ 0.52 / \mathrm{kg}$ of milk (equivalent to US $\$ 14.30$ and US $\$ 17.70 /$ cwt, respectively).

The proportion of each cost classified as a "per cow" or a "per hectare" cost is presented in Table 2. Whenever data could not be separated for individual farmlets because of the structure of the research farm's accounting system (administration, depreciation, electricity costs, repairs and maintenance, standing charges, vehicle expenses), equivalent expenses per cow and per hectare from similar farming systems were extracted from a commercial database used for measuring and benchmarking farm economic performance in Australia and New Zealand (Red Sky, Red Sky Agricultural Pty Ltd., Bacchus Marsh, Australia). Percentage of stock replaced each year (20\%) was not different across farmlets. Therefore, the amount of stock available for sale increased with SR. Asset value, other than stock, was assumed to be the same for the purpose of this analysis.

Data were averaged across years to provide one value/ farmlet. The Red Sky analysis software was then used to compute economic performance variables for respective farmlets. These data were analyzed by ANOVA (GenStat11.1, VSN International, Hemel Hempstead, UK), with SR as the fixed effect. Linear and quadratic contrasts of SR were included in the model.

The strength of the experiment reported is in the ordered arrangement of treatments, with 5 SR under very similar management decision rules evaluated over multiple years. The production and reproduction data were presented by Macdonald et al. (2008), and a summary of the most relevant data from an economics perspective are presented in Table 1 . Briefly, pasture produced $(P=0.11)$ and utilized $(P<0.01)$ per hectare increased by $986 \mathrm{~kg}$ of DM/ha and $2,073 \mathrm{~kg}$ of $\mathrm{DM} / \mathrm{ha}$, respectively, per additional cow/ha increase in SR. Pasture quality increased $(P<0.001)$ with SR, resulting in a linear increase $(P<0.001)$ in energy consumed of 25 GJ of ME/ha for every additional cow/ ha. As a result, milk yield and yields of fat, protein, and lactose per hectare increased $(P<0.01)$ linearly with SR. However, milk yield and yield of milk components per cow declined $(P<0.01)$ because of lower feed availability and the shorter lactation lengths required to manage winter and spring feed supply and cow BCS as SR increased. A limited amount of pasture silage was purchased for the higher SR treatments, increasing purchased feed costs, but the amount of pasture conserved as silage declined linearly $(P<0.01)$ with increasing SR. In addition, the proportion of the farm that had to be cut mechanically (topped) to maintain pasture quality declined linearly $(P<0.01)$ with increasing SR, decreasing labor and pasture maintenance expenses. No difference was observed in 3- or 6-wk in-calf rates or final empty rate and, although SR did not significantly affect the proportion of cows that were anestrous at planned start of mating, actual data pertaining to animal health and breeding costs for individual farmlets were used in the economic analysis. The biological response data are consistent with previously published effects of SR (McMeekan, 1956; Castle et al., 1972; Gordon, 1973; Baker and Leaver, 1986; Fales et al., 1995; Dillon et al., 1995; Kennedy et al., 2006).

Gross revenue, operating expenses, and operating profit at different SR are presented in Table 2, and the sensitivity of operating profit to milk price with increasing CSR is presented in Figure 1, on a per cow and per hectare basis. Additionally, the effect of CSR on operating profit in systems paid for milk components or for fluid milk are separated (Figure 1). Irrespective of system of milk payment, increasing SR and CSR resulted in declines in gross revenue/cow $(P<0.001)$ and operating expenses/cow $(P<0.01)$. However, gross revenue/cow declined to a greater extent than did operating expenses (-NZ $\$ 297$ vs. $-\mathrm{NZ} \$ 134 /$ cow, respectively, for each additional cow/ha, and $-\mathrm{NZ} \$ 18$ vs. $-\mathrm{NZ} \$ 8.6 / \mathrm{cow}$, respectively, for each additional $\mathrm{kg}$ of $\mathrm{BW} / \mathrm{t}$ of $\mathrm{DM}$ available). Therefore, operating profit/ cow declined $(P<0.001)$ with increasing SR and CSR. The decline in operating profit/cow with increasing SR was greater, however, when the milk pricing system was based on milk components than with a pricing system based on fluid milk ( $-\$ 163$ and $-\$ 104$ for each additional cow/ha, respectively). This is because the decline in milk component yield/cow was $10 \%$ greater than the decline in milk yield/cow.

Economic outcomes per hectare followed the opposite trend to those reported per cow, with some subtleties dependent on milk pricing system. For example, gross revenue and operating expenses per hectare increased linearly $(P<0.01)$ with increasing SR and CSR. However, change in gross revenue per hectare was affected by milk payment system and, as a result, operating expenses increased to a greater degree than did gross revenue in systems paid for milk components, but not in fluid milk payment systems. Operating profit per hectare, therefore, followed a quadratic trend with increasing SR $(P=0.1)$ and $\operatorname{CSR}(P=0.08)$ in systems 
Table 2. Effect of stocking rate on gross revenue (NZ\$), operating expenses (NZ\$), operating profit (NZ\$), and return on assets (\%) for farmlets stocked at 2.2, 2.7, 3.1, 3.7, or 4.3 cows / ha over a 3 -yr period

\begin{tabular}{|c|c|c|c|c|c|c|c|c|c|c|c|c|c|c|c|c|}
\hline \multirow[b]{3}{*}{ Item } & \multicolumn{2}{|c|}{ Expense $^{1}$} & \multicolumn{7}{|c|}{ Per cow } & \multicolumn{7}{|c|}{ Per ha } \\
\hline & \multirow{2}{*}{$\begin{array}{l}\text { Per } \\
\text { cow }\end{array}$} & \multirow{2}{*}{$\begin{array}{c}\text { Per } \\
\text { ha }\end{array}$} & \multicolumn{5}{|c|}{ Stocking rate ${ }^{2}$} & \multicolumn{2}{|c|}{$P$-value ${ }^{3}$} & \multicolumn{5}{|c|}{ Stocking rate } & \multicolumn{2}{|c|}{$P$-value } \\
\hline & & & 2.2 & 2.7 & 3.1 & 3.7 & 4.3 & $\mathrm{~L}$ & $\mathrm{Q}$ & 2.2 & 2.7 & 3.1 & 3.7 & 4.3 & $\mathrm{~L}$ & Q \\
\hline Milk sales ${ }^{4}$ & 100 & 0 & 1,813 & 1,605 & 1,506 & 1,314 & 1,182 & $<0.001$ & 0.11 & 4,029 & 4,397 & 4,690 & 4,825 & 4,992 & $<0.01$ & 0.07 \\
\hline Milk sales $^{5}$ & 100 & 0 & 1,610 & 1,392 & 1,321 & 1,157 & 1,103 & $<0.001$ & $<0.001$ & 3,543 & 3,759 & 4,095 & 4,282 & 4,745 & $<0.001$ & $<0.05$ \\
\hline Livestock sales & 100 & 0 & 142 & 163 & 153 & 142 & 153 & 0.98 & 0.74 & 317 & 447 & 477 & 523 & 647 & $<0.01$ & 0.80 \\
\hline Gross revenue ${ }^{4}$ & & & 1,956 & 1,768 & 1,659 & 1,456 & 1,336 & $<0.001$ & 0.12 & 4,346 & 4,844 & 5,168 & 5,348 & 5,639 & $<0.01$ & 0.12 \\
\hline Gross revenue $^{5}$ & & & 1,752 & 1,555 & 1,474 & 1,299 & 1,256 & $<0.01$ & $<0.01$ & 3,860 & 4,206 & 4,572 & 4,805 & 5,392 & $<0.001$ & $<0.05$ \\
\hline Administration & 20 & 80 & 44 & 37 & 34 & 29 & 26 & $<0.01$ & $<0.05$ & 98 & 102 & 104 & 108 & 112 & $<0.001$ & 0.73 \\
\hline Animal health & 90 & 10 & 63 & 61 & 61 & 60 & 59 & $<0.01$ & 0.48 & 140 & 168 & 189 & 219 & 249 & $<0.001$ & 0.06 \\
\hline Breeding and herd testing & 95 & 5 & 33 & 33 & 33 & 33 & 33 & & & 74 & 91 & 102 & 120 & 140 & $<0.001$ & 0.85 \\
\hline Dairy shed & 75 & 25 & 22 & 20 & 18 & 16 & 14 & $<0.001$ & 0.16 & 49 & 54 & 56 & 57 & 61 & $<0.01$ & 0.46 \\
\hline Electricity & 85 & 15 & 36 & 32 & 28 & 23 & 21 & $<0.01$ & 0.16 & 80 & 87 & 88 & 86 & 88 & 0.21 & 0.28 \\
\hline Grazing and forages & 100 & 0 & 100 & 108 & 98 & 98 & 100 & & & 222 & 297 & 305 & 359 & 421 & $<0.01$ & 0.87 \\
\hline Nitrogen & 0 & 100 & 79 & 70 & 65 & 57 & 51 & $<0.001$ & $<0.05$ & 175 & 191 & 204 & 210 & 217 & $<0.01$ & 0.06 \\
\hline Phosphate and potassium & 0 & 100 & 108 & 87 & 77 & 65 & 56 & $<0.01$ & $<0.05$ & 240 & 239 & 239 & 238 & 237 & $<0.01$ & 0.69 \\
\hline Freight & 95 & 5 & 13 & 13 & 13 & 13 & 13 & & & 29 & 36 & 40 & 47 & 54 & $<0.001$ & 0.48 \\
\hline Pasture maintenance & 15 & 85 & 27 & 19 & 16 & 7 & 6 & $<0.01$ & 0.19 & 60 & 53 & 50 & 25 & 25 & $<0.01$ & 0.94 \\
\hline Repairs and maintenance & 50 & 50 & 91 & 81 & 76 & 70 & 66 & $<0.01$ & $<0.05$ & 202 & 222 & 237 & 259 & 280 & $<0.001$ & $<0.01$ \\
\hline Standing charges & 20 & 80 & 68 & 56 & 50 & 43 & 38 & $<0.01$ & $<0.05$ & 150 & 154 & 156 & 158 & 160 & $<0.01$ & 0.07 \\
\hline Vehicle expenses & 65 & 35 & 59 & 54 & 52 & 49 & 47 & $<0.01$ & $<0.05$ & 130 & 148 & 161 & 180 & 198 & $<0.001$ & $<0.05$ \\
\hline Weed and pest & 10 & 90 & 15 & 11 & 11 & 10 & 9 & $<0.05$ & 0.25 & 34 & 29 & 35 & 36 & 36 & 0.30 & 0.80 \\
\hline Wages & 85 & 15 & 343 & 331 & 324 & 317 & 312 & $<0.01$ & $<0.01$ & 761 & 906 & 1,010 & 1,166 & 1,318 & $<0.001$ & 0.08 \\
\hline Depreciation & 50 & 50 & 129 & 115 & 108 & 100 & 94 & $<0.01$ & $<0.05$ & 286 & 315 & 336 & 366 & 397 & $<0.001$ & 0.16 \\
\hline Operating expenses & & & 1,229 & 1,128 & 1,063 & 989 & 946 & $<0.01$ & $<0.05$ & 2,732 & 3,090 & 3,311 & 3,633 & 3,993 & $<0.001$ & 0.36 \\
\hline Operating profitt, & & & 726 & 640 & 596 & 467 & 390 & $<0.001$ & 0.90 & 1,614 & 1,753 & 1,857 & 1,715 & 1,646 & 0.97 & 0.10 \\
\hline Operating profit ${ }^{5}$ & & & 523 & 427 & 411 & 310 & 310 & $<0.01$ & $<0.05$ & 1,128 & 1,116 & 1,261 & 1,172 & 1,399 & 0.10 & 0.28 \\
\hline Return on asset ${ }_{5}^{4}$ & & & & & & & & & & 3.0 & 3.2 & 3.3 & 3.0 & 2.8 & 0.34 & 0.11 \\
\hline 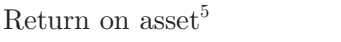 & & & & & & & & & & 2.1 & 2.0 & 2.3 & 2.1 & 2.4 & 0.23 & 0.45 \\
\hline
\end{tabular}

${ }^{1}$ Percentage of each variable attributed to per cow and per hectare costs are presented.

${ }^{2}$ These stocking rates are equivalent to comparative stocking rates ( $\mathrm{kg}$ of $\mathrm{BW} / \mathrm{t}$ of feed $\left.\mathrm{DM}\right)$ of $60,70,76,89$, and 91 , respectively.

${ }^{3} \mathrm{~L}=$ linear; $\mathrm{Q}=$ quadratic

${ }^{4}$ Milk revenue calculated for milk component yield (milksolids price) $=\mathrm{NZ} \$ 4.30$ (reflecting a price of NZ $\$ 3 / \mathrm{kg}$ of milk fat and NZ $\$ 6 / \mathrm{kg}$ of milk protein).

${ }^{5}$ Milk revenue calculated for fluid market milk price (milk price) $=\mathrm{NZ} \$ 0.32 / \mathrm{kg}$ of milk; this is equivalent to US $\$ 10.90 / \mathrm{cwt}$ of fluid milk at US $\$ 0.75 / \mathrm{NZ} \$$ ).

${ }^{6}$ Operating profit is the gross revenue less the operating expenses. 

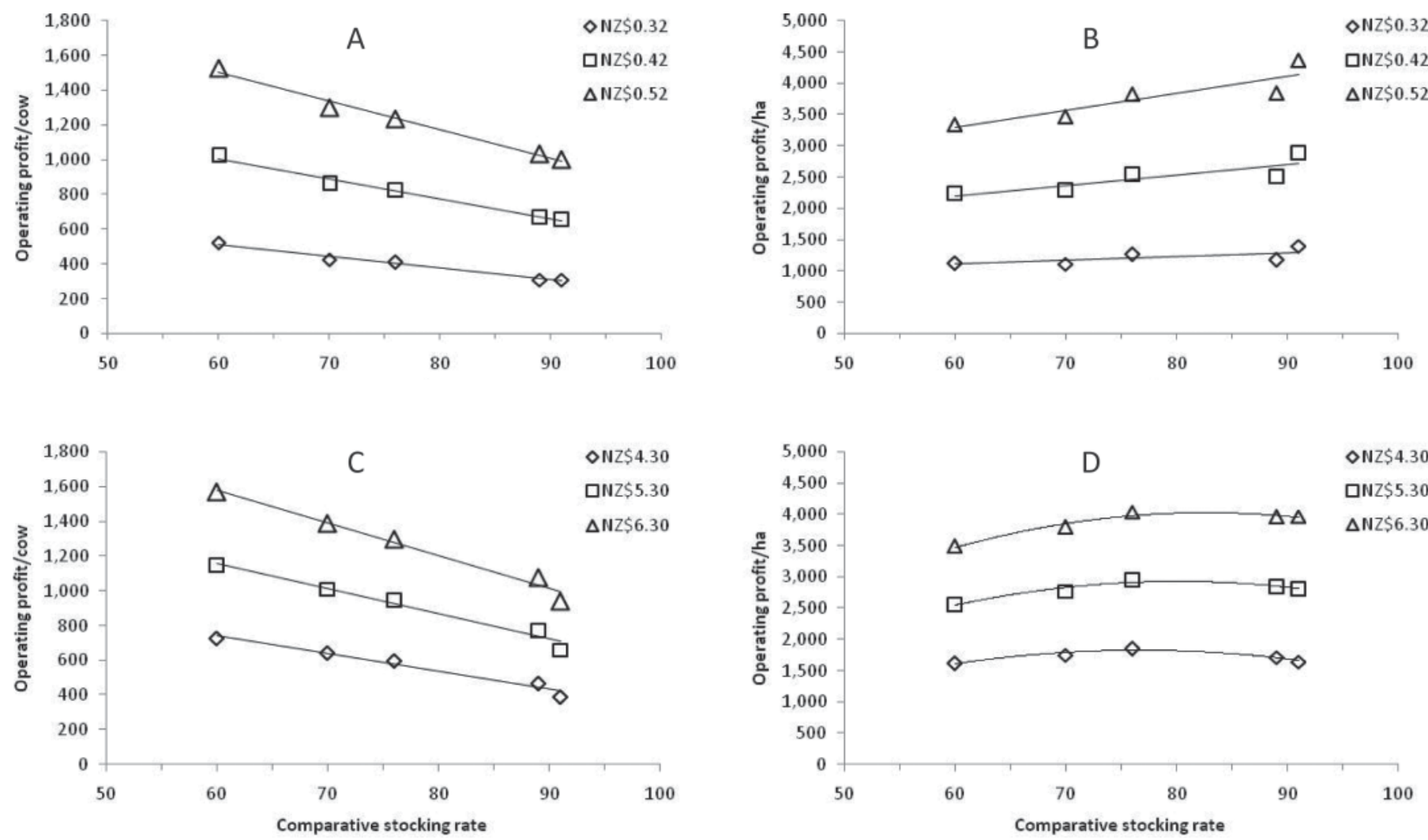

Figure 1. Effect of comparative stocking rate ( $\mathrm{kg}$ of $\mathrm{BW} / \mathrm{t}$ of $\mathrm{DM}$ ), milk payment system (fluid or component pricing), and price received on operating profit (NZ\$) per cow and per hectare. A and B = typical fluid milk payment systems; C and D = systems typically paid for milk components.

with milk component pricing, but increased linearly $(P$ $=0.1$ ) in fluid milk pricing systems. Consistent with these data, Fales et al. (1995) reported a continued increase in operating profit per hectare up to an SR of 4.0 cows/ha in a fluid milk pricing system. However, the data presented highlight that above an SR of 3.3 cows/ha (Table 2) in the environment investigated here or above a CSR of $77 \mathrm{~kg}$ of BW/t of DM (Figure 1), operating profit declines in a milk market based on payment for fat and protein. Return on assets tended to change quadratically with SR in a milksolids price system, similar to the profile of change in operating profit. However, return on assets was not affected by SR or CSR in fluid milk pricing systems.

To conclude, milk production per cow declined and milk production per hectare increased with increasing SR. However, the decline in milk component yield per cow was $10 \%$ greater than the decline in fluid milk yield per cow under the conditions evaluated here. As a result, operating profit per hectare declined 8 or $10 \%$ when SR was 1 cow/ha below or above 3.3 cows/ha, respectively, where milk pricing was based on payment for fat and protein; a decrease or increase in CSR of 10 $\mathrm{kg}$ of $\mathrm{BW} / \mathrm{t}$ of $\mathrm{DM}$ from $77 \mathrm{~kg}$ of $\mathrm{BW} / \mathrm{t}$ of $\mathrm{DM}$ reduced operating profit per hectare by $4 \%$. In comparison, operating profit per hectare increased linearly in fluid milk markets up to an SR of 4.4 cows per hectare and a CSR of $91 \mathrm{~kg}$ of BW/t of DM. These trends were evident irrespective of milk price. Further research could investigate the interaction between stocking rate, breed or genetic strain, and calving date and spread.

\section{ACKNOWLEDGMENTS}

The authors acknowledge the technical ability of C. Leydon-Davis and J. Lee (DairyNZ), the statistical expertise of B. Dow (DairyNZ), and all the help afforded them by No 2. Dairy staff, in particular, M. Coulter. This work was funded by New Zealand Dairy Farmers through DairyNZ.

\section{REFERENCES}

Baker, A.-M. C., and J. D. Leaver. 1986. Effect of stocking rate in early season on dairy cow performance and sward characteristics. Grass Forage Sci. 41:333-340. 
Castle, M. E., E. MacDaid, and J. N. Watson. 1972. Some factors affecting milk production from grassland at the Hannah Institute, 1951-70. J. Br. Grassl. Soc. 27:87-92.

Dillon, P., S. Crosse, G. Stakelum, and F. Flynn. 1995. The effect of calving date and stocking rate on the performance of springcalving dairy cows. Grass Forage Sci. 50:286-299.

Dillon, P., J. R. Roche, L. Shalloo, and B. Horan. 2005. Optimising financial returns from grazing in temperate pastures. Pages 131-147 in Utilisation of Grazed Grass in Temperate Animal Systems. Proc. Satellite Workshop of the XXth International Grassland Congress, Cork, Ireland. Wageningen Academic Publishers, Wageningen, the Netherlands.

Fales, S. L., L. D. Muller, S. A. Ford, M. O'Sullivan, R. J. Hoover, L. A. Holden, L. E. Lanyon, and D. R. Buckmaster. 1995. Stocking rate affects production and profitability in a rotationally grazed pasture system. J. Prod. Agric. 8:88-96.

Gordon, F. J. 1973. The effect of high nitrogen levels and stocking rates on milk output from pasture. J. Br. Grassl. Soc. 28:193-201.

Hanson, G. D., S. Cunningham, A. Ford, L. D. Muller, and R. L. Parsons. 1998. Increasing intensity of pasture use with dairy cattle: An economic analysis. J. Prod. Agric. 11:175-179.

Kennedy, E., M. O'Donovan, J. P. Murphy, F. P. O'Mara, and L. Delaby. 2006. The effect of initial spring grazing date and subsequent stocking rate on the grazing management, grass dry matter intake and milk production of dairy cows in summer. Grass Forage Sci 61:375-384.

Kriegl, T. 2001. Wisconsin grazing dairy profitability analysis-A preliminary five-year comparison of the cost of production of selected conventional and grazing Wisconsin dairy farms. University of Wisconsin Centre of Dairy Profitability, Madison.

Macdonald, K. A., J. W. Penno, J. A. S. Lancaster, and J. R. Roche. 2008. Effect of stocking rate on pasture production, milk production and reproduction of dairy cows in pasture-based systems. J. Dairy Sci. 91:2151-2163.

McGrath, J. M., J. W. Penno, K. A. Macdonald, and W. A. Carter. 1998. Using nitrogen to increase dairy farm profitability. Proc. N.Z. Soc. Anim. Prod. 58:117-120.

McMeekan, C. P. 1956. Grazing management and animal production. Page 146-156 in Proc. VII Int. Grassl. Congr., Massey Agricultural College, Palmerston North, New Zealand. G. J Neale, ed. Wright and Carman Ltd., Wellington, New Zealand.

Roche, J. R., P. G. Dillon, C. R. Stockdale, L. H. Baumgard, and M. J. VanBaale. 2004. Relationships among international body condition scoring systems. J. Dairy Sci. 87:3076-3079.

White, S. L., G. A. Benson, S. P. Washburn, and J. T. Green Jr. 2002. Milk production and economic measures in confinement or pasture systems using seasonally calved Holstein and Jersey cows. J. Dairy Sci. 85:95-104 